\title{
Selection of Suitable Drilling Parameters for obtaining high Rate of Penetration in Majnoon Oilfield
}

\author{
Majid M. Majeed and Ayad A. Alhaleem
}

Petroleum Engineering Department/College of Engineering/University of Baghdad

\begin{abstract}
Several directional wells have been drilled in Majnoon oilfield at wide variation in drilling time due to different drilling parameters applied for each well. This technical paper shows the importance of proper selection of the bit, Mud type, applied weight on Bit (WOB), Revolution per minute (RPM), and flow rate based on the previous wells drilled. Utilizing the data during drilling each section for directional wells that's significantly could improve drilling efficiency presented at a high rate of penetration (ROP). Based on the extensive study of three directional wells of 35 degree inclination (MJ-51, MJ-52, and MJ-54) found that the applied drilling parameters for MJ-54 and the bit type within associated drilling parameters to drill 36", 24", 16" and 12 1/4" hole sections is the best, although the drilling parameters in $81 / 2$ " hole section for MJ-51 and selected bit type are the best for future wells.
\end{abstract}

Keywords: Drilling parameters, Bit type, Majnoon oilfield, and Hole section

Received on 09/09/2018, Accepted on 04/11/2018, published on 30/03/2019

https://doi.org/10.31699/IJCPE.2019.1.9

\section{1- Introduction}

Majnoon oil field was discovered in 1975 by Braspetro Oil Company. The field was named Majnoon which means 'crazy' in Arabic in reference to the dense accumulation of oil in the area. The field located $60 \mathrm{~km}$ from Basra city in southern [1] Fig. 1.

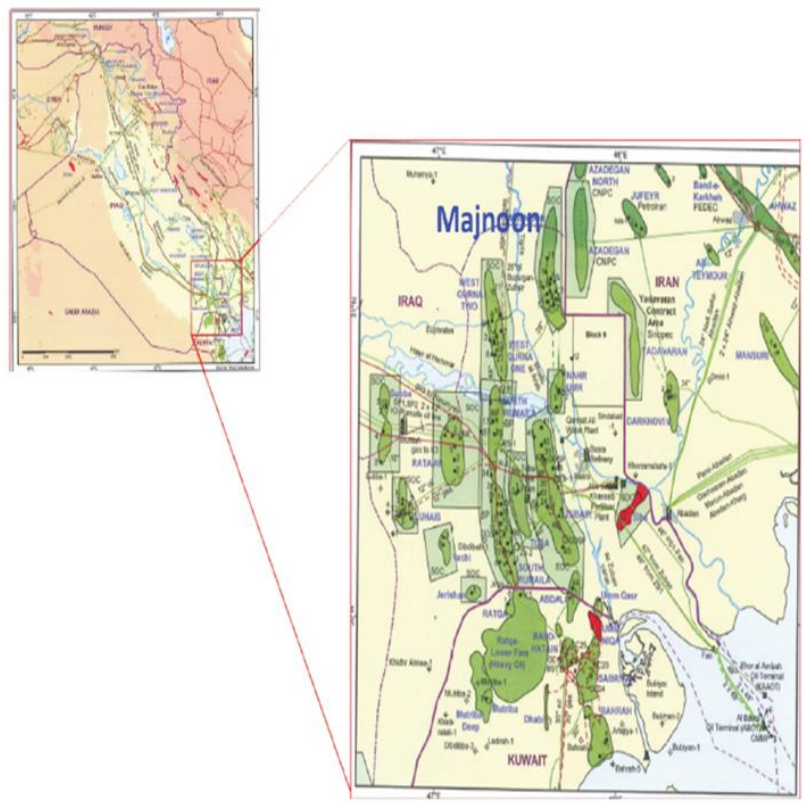

Fig. 1. Majnoon field location map [1]
It is generally known that time is money and improving the ROP will reduce the cost of the well, the major factors that affect the drilling time and costs are bit type, mud type, WOB, RPM and flow rate, therefore the primary criteria of drilling optimization is an economical approach resulted in optimization based on the correct selection of WOB, RPM, and bit types which produce the highest ROP and consequently the minimum cost of drilling [2].

In Majnoon oil field, the drilling time required to reach section total depth (TD) varied from one well to another, therefore a thorough analysis conducted to identify the shortest time per each section.

\section{2- Well Design}

The wells in Majnoon oil field were drilled either to Mishrif carbonates, Nahr-Umer Sands, or Zubair Sands.

First, the top hole section is drilled across Upper Fars formation with 36 " bit to an approximately $100 \mathrm{~m}$ depth where the weak formations existed, and 30" conductor casing is cemented in place to ensure that the water table had been adequately cased-off .

Second, the surface hole section is drilled to seal off the unconsolidated formations which are typically consists of Clay and Sands with 24" bit to $600 \mathrm{~m}$ depth.

The $185 / 8 "$ surface casing is set vertically and cemented to surface and the Kick-off point designed in the next hole section at sufficient distance below the previous casing shoe depth [3]. 
Third, the intermediate section is drilled with 16 " bit to $1500 \mathrm{~m}$ across Lower and Ghar formations.

The 13 3/8" casing is run and cemented, $150 \mathrm{~m}$ inside the previous casing. Next is the second intermediate 12 $1 / 4$ " section is drilled to $2500 \mathrm{~m}$ through Dammam, UER, Aliji, shiranish, Hartha, Saadi, Tanuma, and Khassib formations.
The $95 / 8$ " casing is run and cemented, $100 \mathrm{~m}$ inside the previous casing section. Finally, the $81 / 2$ " production section is drilled to reach well Total Depth (TD) and desired Reservoir zone; the 7" casing liner run and cemented $150 \mathrm{~m}$ inside the previous casing [3].

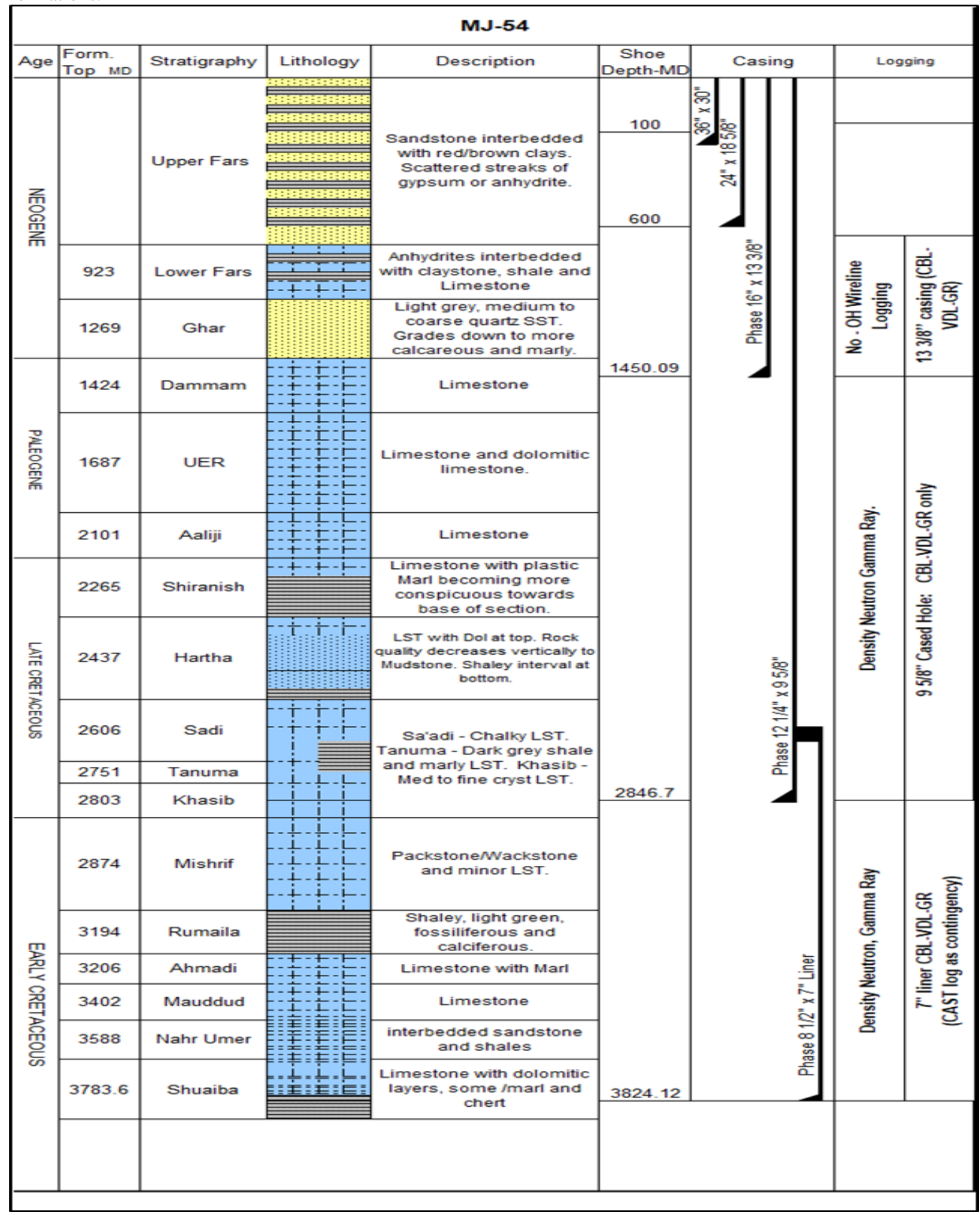

Fig. 2. Stratigraphic column of Majnoon Oil field [1] 


\section{3- Analysis and Discussion}

The previously drilled wells (MJ-51, MJ-52, and MJ54) were researched thoroughly and from the findings discovered the optimized drilling parameters in Majnoon oilfield. Optimization process characterized by the concentrating on the WOB, RPM, flow rate, bit type, and mud type, where the ROP rely heavily on these variables.

Based on the data collected from (MJ-51, MJ-52, and MJ-54) wells that were drilled in Majnoon oilfield, the shallow formations were described in two hole sections 36 " and 24" sections. The major issue encountered during drilling is the bit balling criteria due to clay hydration, therefore it is significant to know that in MJ-54 were drilling parameters largely different compared with MJ-51 and MJ-52, mud salinity was 65,000 PPM rather than 45,000 PPM in previous wells, however bit type used in studied wells is the Tri-cone bit,[4] Table 1.

Table 1. 36" and 24" Hole section drilling parameters [5]

\begin{tabular}{llllll}
\hline $\begin{array}{l}\text { Well } \\
\text { name }\end{array}$ & Bit type & $\begin{array}{l}\text { WOB } \\
(\mathrm{klbs})\end{array}$ & RPM & $\begin{array}{l}\text { Flow rate } \\
(\mathrm{GPM})\end{array}$ & $\begin{array}{l}\text { ROP } \\
(\mathrm{m} / \mathrm{hr})\end{array}$ \\
\hline MJ-51 & XT1GRC & $25-30$ & $60-90$ & $350-500$ & 10 \\
MJ-52 & XT1GRC & 20 & $60-80$ & $350-550$ & 8 \\
MJ-54 & XT1GRC & $15-20$ & $90-100$ & $550-950$ & 14.5 \\
\hline
\end{tabular}

In well MJ-54, the 36" and 24" hole sections shows the highest flow rate and RPM at 90-100 with minimal WOB 15-20 kilo pounds (klbs) is beneficial to drill at higher ROP of $14.5 \mathrm{~m} / \mathrm{hr}$, this is clear indications that the bit cleaned efficiently from the clay with 550-950 gallon per minute (GPM). These combinations of drilling parameters are likely to use for future wells [5].

Second, the 16" hole section in three wells was a buildup section and 35 degrees of inclination is the maximum inclination, Table 2.

Table 2. 16" Hole section drilling parameters [5]

\begin{tabular}{llllll}
\hline Well name & Bit type & $\begin{array}{l}\text { WOB } \\
(\mathrm{klbs})\end{array}$ & RPM & $\begin{array}{l}\text { Flow rate } \\
(\mathrm{GPM})\end{array}$ & $\begin{array}{l}\text { ROP } \\
(\mathrm{m} / \mathrm{hr})\end{array}$ \\
\hline MJ-51 & XT02SC & $25-40$ & 120 & 800 & 8 \\
MJ-52 & SFD75DH & $20-35$ & 150 & $900-950$ & 12 \\
MJ-54 & SF76H & $20-35$ & 150 & $900-950$ & 18 \\
\hline
\end{tabular}

It is important to note that every well drilled a new bit used with slight changes to the applied drilling parameters; the average ROP of $18 \mathrm{~m} / \mathrm{hr}$ was achieved with PDC bit type (SF76H), this is the highest ROP compared to the offset wells, due to the successful bit selection drilled the entire interval. [6] Table 3.

Table 3.12 1/4" Hole section drilling parameters [3]

\begin{tabular}{|c|c|c|c|c|c|}
\hline $\begin{array}{l}\text { Well } \\
\text { name }\end{array}$ & Bit type & $\begin{array}{l}\text { WOB } \\
\text { (klbs) }\end{array}$ & RPM & $\begin{array}{l}\text { Flow rate } \\
(\mathrm{GPM})\end{array}$ & $\begin{array}{l}\mathrm{ROP} \\
(\mathrm{m} / \mathrm{hr})\end{array}$ \\
\hline MJ-51 & MME65DM & $15-25$ & 140 & $650-700$ & 10 \\
\hline MJ-52 & MMD75H & $15-20$ & 150 & $600-700$ & 12 \\
\hline MJ-54 & MMD75H & $25-35$ & 150 & $750-800$ & 15 \\
\hline
\end{tabular}

The bits for MJ-52 and MJ-54 is the same type but ROP in MJ-54 is $25 \%$ higher than the ROP in MJ-52 this is due to more WOB implemented during drilling operation with 800 GPM flow rate [6].

It is important to note that in $81 / 2^{\prime \prime}$ hole section drilling parameters WOB and RPM that described in Table $\mathbf{4}$ are not largely different from one well to another, however the bit type (MME74H) in well MJ-51 showed impressive performance with $24 \mathrm{~m} / \mathrm{hr}$ ROP, although the exceptional flow rate worked successfully to drill at $24 \mathrm{~m} / \mathrm{hr}$ [6].

Table 4. 8 1/2" Hole section drilling parameters [5]

\begin{tabular}{llclll}
\hline $\begin{array}{l}\text { Well } \\
\text { name }\end{array}$ & Bit type & $\begin{array}{l}\text { WOB } \\
(\mathrm{klbs})\end{array}$ & RPM & $\begin{array}{l}\text { Flow rate } \\
(\mathrm{GPM})\end{array}$ & $\begin{array}{l}\text { ROP } \\
(\mathrm{m} / \mathrm{hr})\end{array}$ \\
\hline MJ-51 & MME74H & $20-25$ & $120-150$ & $500-620$ & 24 \\
MJ-52 & MME75R & $15-20$ & $100-150$ & $500-550$ & 13 \\
MJ-54 & MME75R & $15-20$ & $100-140$ & 500 & 12 \\
\hline
\end{tabular}

\section{4- Conclusions}

1- It's important to know that during drilling (36" and 24") hole sections in MJ-54 with higher flow rate and RPM compared with the previous wells, there was no bit balling encountered while drilling clay interval, achieved consistent ROP of $14.5 \mathrm{~m} / \mathrm{hr}$.

2- In well MJ-54, while drilling 16" hole section an improved drilling performance was observed with the new bit design (SF76H).

3- In well MJ-54, while drilling 12 1/4" hole section, it's clearly indicates that an increase in WOB had significant effect on the ROP, WOB varies directly with ROP at the acceptable flow rate required to clean the bit.

4- In well MJ-51, while drilling 8 1/2" hole section, proper bit selection worked together with associated drilling parameters resulted in great drilling performance, a huge improvement compared to the offset wells.

\section{Nomenclatures}

GPM: $\quad$ Gallon per minute

PDC: $\quad$ Polly crystalline diamond compact

PPM: $\quad$ Parts per million

ROP: $\quad$ Rate of penetration

RPM: $\quad$ Round per minute

TD: $\quad$ Total Depth

WOB: Weight on bit 


\section{References}

[1] Miguel Armenta, Rob Tinkhof, "improving drilling performance at Majnoon Oilfield", UAE: SPE/IADC drilling conference and Exhibition, 2013.

[2] M.F. Al Dushaishi and R. Nygaard, "Selecting of optimum drilling parameters by incorporating drilling efficiency models", Texas: IADC/SPE drilling conference and Exhibition, 2016.
[3] Marc- Le Vesconte ," The Majnoon Field - A case study of Drilling Operations in Remote area of Iraq" Texas: SPE/ IADC Drilling conference and Exhibition, 2014.

[4] South Oil company" Final well Reports", Iraq: 2014.

[5] South Oil company" Mud logging Data", Iraq: 2014.

[6] South Oil company" Bit records", Iraq: 2014.

\section{اختيار معاملات الحفر المناسبه لزيادة معدل الاختراق في حقل مجنون النفطي}

تم حفر العديد من الابار المائله في حقل مجنون النفطي باستخدام معاملات حفر مختلفه لكل بئر لذلك الوقت اللازم لاكمال الحفر يختلف من بئر الى اخر. هذه الدراسه تبين اهميه اختيار نوع الحافره ومعاملات الحفر الاخرى المتمتله بالوزن المسلط على الحافره والسرعه دوران عمود الحفرومعدل الجريان اعتمادا على معلومات الابار المحفوره مسبقه في حقل مجنون النفطي اعتماد البيانات الحقليه للابار المحفورة مسبقا تشكل مصدرا اساسيا لتحسين معدل اختراق الحافره, لللك تم اجراء دراسه مكثقه لثالثه ابار مائله وبدرجه 35 (مجنون 51,مجنون 52,مجنون54) حيث تم استتناج انه معاملات الحفرونوع الحافره المستخدمه في (مجنون 54) الانسب لحفر مقاطع (36,24,16,12.25)انج بينما معاملات الحفر المستخدمه لحفر مقطع (8.5) في (مجنون 51) هي الانسب لحفر الابار مستقبلا". 